\title{
Gastrointestinal Stromal Tumor Pathologic TNM Finding v8
}

National Cancer Institute

\section{Source}

National Cancer Institute. Gastrointestinal Stromal Tumor Pathologic TNM Finding v8. NCI Thesaurus. Code C136754.

A pathologic finding about one or more characteristics of gastrointestinal stromal tumor, following the rules of the TNM AJCC v8 classification system. 